\title{
A Study on the Cost of Production in Film Project Management: Taking Small-Budget Films in China as an Example
}

\author{
Xiaolu Lu \\ National Institute of Development Administration of Thailand, Bangkok, Thailand \\ Email: 178874136@qq.com
}

How to cite this paper: Lu, X.L. (2019) A Study on the Cost of Production in Film Project Management: Taking Small-Budget Films in China as an Example. Open Journal of Social Sciences, 7, 75-88. https://doi.org/10.4236/jss.2019.73006

Received: February 1, 2019

Accepted: March 5, 2019

Published: March 8, 2019

Copyright $\odot 2019$ by author(s) and Scientific Research Publishing Inc. This work is licensed under the Creative Commons Attribution International License (CC BY 4.0).

http://creativecommons.org/licenses/by/4.0/

\section{(c) (i) Open Access}

\begin{abstract}
At present, Chinese film has been becoming industrialized with the production management system still being imperfect. Small-budget films account for the largest proportion of Chinese film output while with the problems in production management being the most, which influences the development of the entire cultural industry to a certain extent. Among them, the waste of funds caused by management problems emerges endlessly. In this article, in-depth interviews with nine veterans in the industry and multiple case studies into six small-cost film crews for practical observations are combined and the cost control problem in small-cost films is explained from the perspective of project cost elements for the first time. Four aspects of personnel expenses, material costs, equipment rental expenses and other living expenses are analyzed and discussed and the details of the cost and the hidden factors are studied to expand the application of the theoretical framework of project cost elements in this field.
\end{abstract}

\section{Keywords}

Film Project, Cost of Production, Small-Budget Films in China

\section{Introduction}

In some developed countries in the West, the film has become the core of the cultural industry with its operational management experience being quite mature [1]. For example, every aspect of the film production management in Hollywood in the United States is relatively mature after years of development [2]. The Chinese film industry really got off the ground in 2002, and its production management mechanism was relatively backward with a series of problems 
emerging in the process of production management [3]. Due to the small amount of funds and the limited allocation of resources in all aspects, many problems have been highlighted in the production management process of small-budget films. At present, the project management of the small-budget films accounting for the largest proportion of the total Chinese film production is chaotic, and the management of the actors is especially in utter disorder, which has caused serious problems to the production unit in producing small-budget film. The problem has brought huge losses to the cycle, quality and cost of film production, deeply affecting the international status of Chinese film. Consequently, there exists such a situation that Chinese film production ranks first in the world with only a very small number of films profitable and most of them turning out to be with deficit. In 2017, less than $10 \%$ of all the Chinese films can be profitable [4], which impresses the development of the entire cultural industry to a certain extent.

Based on a clear investment quota, the film project begins to formulate a production plan. Once the production plan is determined, detailed planning is required for the use and distribution of funds throughout the film-producing period [5]. As far as small-budget films are concerned, there are still many management deficiencies in the process of producing films, which leads to waste of funds, especially the waste of funds caused by many human factors, and ultimately results in unnecessary cost overruns. In this article, the author studies, concludes and summarizes the cost overruns and cost savings involved in the production process of small-budget film from the perspective of cost control with an aim to help managers avoid unnecessary expenditures, contain unnecessary losses and successfully complete the film production on the basis of saving funds. In the film production, much consumption is abstract. High costs do not necessarily bring about high benefit, and low costs do not necessarily lead to low quality. For example, providing there are two similar films in scale with their production cost varying greatly, the problems are impossible to be penetrated for investors and managers lack of experience. As a matter of fact, laymen are involved in investing and managing most of the current small-budget films. In the production process of the film, the five main aspects involved in the costs are: personnel expenses; material costs, digital photography costs, equipment rental expenses, and other living expenses [6]. Among them, small-budget films' demand for digital photography cost including special effects, film trick and other expenses is small. In addition, the digital photography link belongs to the category of post-production, which is beyond the scope of this article. Therefore, the author will discuss and analyze the personnel expenses, material costs, equipment rental expenses and other living expenses in this paper.

Unless specified, the small-budget films mentioned in the paper refer to "small-budget films in China", and the currency mentioned in the paper is "RMB".

The definition of "small-budget film" is measured by the investment costs of the film, which is not uniform in the industry and academia. The "small-budget 
films" in this article are defined as "a film with an investment of less than 10 million" based on the statements of the academic authority and the mainstream of the industry [7].

\section{Literature Review}

Project management originated from the US military and mostly referred to defense project management, and the project managers or directors did not involve direct financial interests. Therefore, cost control and management seemed insignificant for quality and time. With the passage of time, the concept of project management has gradually been accepted by the business community. It was first applied in the construction industry. Since then, the importance of cost has gradually been increased and has been called as the three elements of project management together with time and quality. In most projects, cost overrun is a long-standing problem, and the participation of many stakeholders in project production inevitably leads to project overruns [8]. The determination of the production scope has a great impact on the cost control. That the scope of the project is unchanged will help to control the cost more favorably. The final cost will increase if the production rhythm of the project is changed because of certain factors [9].

At present, there is no perfect and effective cost control system for film production in China. Therefore, the problems in the control on cost emerge in an endless stream. The main contradiction lies in the lack of a sound cost control system, namely, horizontal responsibility system should be implemented from the production director to the various departments of the crew, and the vertical responsibility system should be implemented from the production director to all the staff; the objects of cost control should be standardized to meet the requirements of the cost control and filming characteristics of the film crew, as well as the organization characteristics of the film crew; appropriate cost control method should be selected according to the characteristics of the film crew [10]. The film cost control in China is still in its infancy, and there are certain problems in all aspects. In particular, cost control personnel should shift from the role of single financial accountant to the role of management accountant [11]. Producers and film crew financers need to understand the characteristics of film projects and be aware of the impact of cost management on film production. Appropriate cost control can help to improve the overall level of the film in addition to reducing project costs [12]. The cost management method in project management can effectively help to control the cost management of film projects, which makes the crew resources more optimized and helps to improve the quality and profit of the film [13]. The combination and interaction of activity-based costing and budgetary control can help to achieve a significant degree of target control over film production costs [14]. The development of the Chinese film industry will continue to be advanced in the future, and the favorable accounting of costs will also affect the correct decision-making of film producers [15]. 
The existing literature has laid the status of cost elements in project management. As to the cost of film project production, the status quo of the organization and the strategy of cost management are explained and discussed in detail. However, the existing studies mainly based on the macroscopic perspective focus on the form of the control and the cost management strategy, while ignore the characteristics of the film crew and the specific reasons for the high cost and have difficulties in explaining the deeply hidden unregistered logic of the cost problem. Therefore, based on the logic and generality of the film production management in formulating cost control method and strategy, the author has deeply explained and discussed the details of the cost problem caused in the film production process and classified the attributes of the cost problem in this article.

\section{Methodology}

In this study, practical observations and in-depth interviews (Table 1) are applied to collect data for qualitative research analysis.

1) In the cases of six small-budget film crews, the researchers have entered and worked in the crews and conducted in-depth observation and research on the issues of costs in the crew to form a multi-case study based on replication logic. Multi-case studies are supplemented by iterations of things in different environments to make research conclusions more stable and reliable and more general [16].

Table 1. Methods of Collecting Data.

\begin{tabular}{|c|c|c|}
\hline objects Methods & Practical investigation & In-depth interviews \\
\hline A & $\begin{array}{l}\text { Film "Youth hey up" } \\
\text { About } 5 \text { million investment }\end{array}$ & $\begin{array}{l}\text { Mr. Zhou Yi (scene filmmaker, producer) } \\
\text { Interview time: } 69 \text { minutes }\end{array}$ \\
\hline B & $\begin{array}{l}\text { Film "Crazy chef" } \\
\text { About } 3 \text { million investment }\end{array}$ & $\begin{array}{l}\text { Mrs. Zhou Yulan (producer) } \\
\text { Interview time: } 69 \text { minutes }\end{array}$ \\
\hline $\mathrm{C}$ & $\begin{array}{l}\text { Film "Kiss kiss da" } \\
\text { About } 3 \text { million investment }\end{array}$ & $\begin{array}{l}\text { Mr. Wu Weidong (coordination filmmaker, } \\
\text { unit production manager) Interview time: } 42 \text { minutes }\end{array}$ \\
\hline $\mathrm{D}$ & $\begin{array}{l}\text { Film “Mama's taste" } \\
\text { About } 3 \text { million investment }\end{array}$ & $\begin{array}{l}\text { Mr. Lei Qing (life scene filmmaker) } \\
\text { Interview time: } 61 \text { minutes }\end{array}$ \\
\hline $\mathrm{E}$ & $\begin{array}{l}\text { Film "I am a good therapist for love" } \\
\text { About } 10 \text { million investment }\end{array}$ & $\begin{array}{l}\text { Mr. Jin Shuang (scene filmmaker) } \\
\text { Interview time: } 43 \text { minutes }\end{array}$ \\
\hline $\mathrm{F}$ & $\begin{array}{l}\text { Film "The goddess encountered the paparazzi" } \\
\text { About } 3 \text { million investment }\end{array}$ & $\begin{array}{l}\text { Mr. Ma Yong (director) } \\
\text { Interview time: } 61 \text { minutes }\end{array}$ \\
\hline G & & $\begin{array}{l}\text { Mr. Ma Yi (unit production manager) } \\
\text { Interview time: } 61 \text { minutes }\end{array}$ \\
\hline $\mathrm{H}$ & & $\begin{array}{l}\text { Mr. Zhou Dayan (unit production manager) } \\
\text { Interview time: } 90 \text { minutes }\end{array}$ \\
\hline I & & $\begin{array}{l}\text { Mr. Yuan Ailin (planner) } \\
\text { Interview time: } 45 \text { minutes }\end{array}$ \\
\hline
\end{tabular}


2) The researcher has conducted one-to-one in-depth interviews with veterans of the nine small-budget film production management teams. The issues of costs in the film crew have great hidden features, and the experienced small-budget film crews have an intuitive and visual feeling about the hidden features of the industry, so the information obtained from their interviews is very suitable for the study in this paper. In-depth interviews help to trigger interviewees to share relevant events, their experience of successes and failures, and enable interviewees and researchers to participate in understanding the researched questions [17]. The researcher in this article will conduct face-to-face, in-depth and long-term interviews with people who have years of experience in film production management and artistic creation in small-budget film production. The interview is carried out around the research content in this article by virtue of semi-structured and open-ended questioning methods. The respondent has been invited to discuss topics around the following points. 1) Which processes of small-budget films production are usually found with overspending; 2) Which processes of small-budget films production are most likely to help save costs; 3 ) What is the relationship between small-budget film production and the film quality and filming cycle; 4) How to balance the relationship between them? And what is their importance in film production? The researcher also needs to carefully watch what the interviewee is doing and saying during the interview process, and perform on-the-spot recording or brain memory on the tone, facial expression, expressions in their eyes, and speech rhythm of the interviewee, so as to summarize deeper and more implicit implication with combining the text content.

\section{Results}

In the production of small-budget films, the personnel expenses account for a large proportion. The investment in the personnel accounts for about $35 \%$ of the total investment in the absence of big-name actors, while the investment cannot be accurately estimated if there are big-name actors in the film and the maximum can account for $60 \%$ of the total investment. The personnel are divided into actors and staff, and their ideas about wage income are completely different. The wage income of all staff is hardly flexible, because the personnel are in want of making money. Among the staff, the personnel in the bottom of strata pay more attention to the income, for example, the field workers and grips almost rely on manual labor to create value. Basically, their jobs do not involve professional skills or management skills and making money is the only goal and motivation to them. Also, their income is relatively low with wage between 150 and $200 \mathrm{RMB}$ per person per day. Therefore, the cost investment into them is relatively fixed and there is no accommodation. Professional and technical staff and general management personnel have to take the career prospects and interpersonal relationship maintenance into consideration in addition to making money; therefore, there is a small space of so-called favor price out of gratitude for them. 
The scope of favor price depends on the specific interest relationship and human relationship between the party and the film crew. The flexible favor price between the two is roughly between $20 \%$ and $50 \%$ of the party's own pricing. The pricing of the party is determined by his or her own professional ability and working experience. High pricing is determined by excellent professional ability and rich working experience. On the contrary, the pricing of the newly debuted personnel is usually low due to their limited experience and ability, because the most needed for them is to accumulate industry experience. Accordingly, the film crew selects appropriate personnel based on their own cost investment and social network. In general, the cost investment in personnel is relatively fixed, and there is no excessive cost savings, while there is a lot of room for the actor's remuneration income. In this study, the actors are divided into two categories, the main actors (the lead, the supporting actors) and non-main actors (the guest actors, the extras). The remuneration of the extras and some guest actors is relatively fixed. Generally speaking, the film crew usually contacts the lead of the extras and recruits the actors through the lead. Their price is roughly 80 to 120 RMB per day. The actors with good-looking appearance and excellent acting skills can be invited as guest actors with the remuneration generally no more than 300 RMB per day. As for them, it is also a privilege to be selected as guest actors and they may not care much about the remuneration. The film crew pays the remuneration to the lead of the extras, and then the latter allocates the remuneration according to the distribution ratio agreed with the actors in advance. Since the right to choose the lead of the extras and the guest actors is controlled by the casting directors, there are many casting directors who use the right to exchange interests with the lead of the extras. Therefore, it is possible to breed corruption and other issues, and due to the downward shift of right, there may be two consequences: the actors' remuneration is reduced, which leads to decrease in working enthusiasm or low quality of the actors; In addition, the increased overall cost will put pressure on the funding of the film crew. For example, the casting director will draw a percentage of $20 \mathrm{RMB}$ from an extra actor; providing there are 80 extras per day and the shooting duration lasts for five days, then the total percentage drawn from the sum of money is $20 \times 80 \times 5=$ $8000 \mathrm{RMB}$. The gray income is equivalent to the salary income of the casting director. However, the commission fee of the guest actor is not included. The author has firstly tried being the casting director in the research of this study, and the salary was 5000 RMB. Rare stars or big names are invited to be the main actors in the small-budget films, because the production cost limits the cast, and the price of the ordinary professional actors is more flexible. The purpose of professional actors is different from that of the general staff in the film crew. The former usually go after artistic achievements and are not entirely for making money. In general, they hope to become famous, so if there are good roles for them, they may not put the amount of remuneration in the first place. The more experienced the actor is, the higher the remuneration is. compared to the expe- 
rienced actors, the remuneration of the newcomers is more uncertain. However, as for selecting the film actors, an experienced actor may not have an advantage over the newcomer, and it is possible that the newcomer with the temperament being more suitable for the role designed in the film is more likely to be liked and recognized by the audience. Therefore, it is needed to be more careful in selecting the actors with high remuneration when producing small-budget films. Many students in colleges and universities or actors who have just graduated from school always have professional foundation and skills, but lack practical experience. Thus, it is more likely to invite them to participate in the shooting with less remuneration. It is more advantageous to invite newcomers if they are suitable for the designed roles. As to the price of a same role, the pricing of the newcomer may be $2000 \mathrm{RMB}$, while the experienced actor may make an offer of $100,000 \mathrm{RMB}$, so the difference in remuneration will cause the film crew to prefer new actors. In fact, other unknown actors in addition to the stars and big names make no difference in hearts of the vast majority of viewers. In the choice of the leading actors, the casting director has certain recommendation rights. Some casting directors will recommend a number of actors to the director or producer and privately agree with the actors on that the latter will return to the casting directors a certain proportion of the recommendation as referral fee if they are selected by the film crew. This method greatly increases the cost of the cast for the film crew. In the process of shooting, some actors will gradually show their dissatisfaction with the recommendation, which will seriously affect the normal shooting and result in more production cost by the crew. And it is imaginable that shooting effect is not as good as people wishes. In addition to the previous percentage of the heads of the extras, the gray income of the casting director ranges from a few thousand to over ten thousands. This is not a small amount for small-budget films. In terms of the choice of the leading actors, some actors may choose to invest in the film crew for themselves or their children in order to get a chance on camera. The film crew will consider the conditions and investment amount of the actors and other factors. After weighing the pros and cons, the film crew makes the final decision of whether to accept or not. As for small-budget films, right actors should be chosen for the roles rather than actors blindly paid at high prices. The statistics of the leading actors' remuneration in the six cases of this study are as follows (Table 2). In order to ensure the privacy of the parties, the lowercase English letters are used instead of the specific actors' names. It is able to see that the income of the actors selected through the colleges and universities is generally low; relatively speaking, the income of the actors selected through the agent company is relatively high, because the agents will take about $50 \%$ of the remuneration. Recommended professional actors refer to professional actors who are recommended to join the shooting. Recommended social actors refer to social actors who are recommended to join shooting. The table shows that the cost of the professional actors and that of non-professional actors are actually about the same. Professional actors recommended due to gra- 
titude or other interests are usually paid at a low price in addition to some exceptional cases. The non-professional actors who are recommended to join the shooting are also low-paying, and some even act for no remuneration. However, there exist special cases in which non-professional actors can get high remuneration, and most of the people who can bring in the investment are children actors.

Table 2. The Remuneration statistics table of the research objects-main actors.

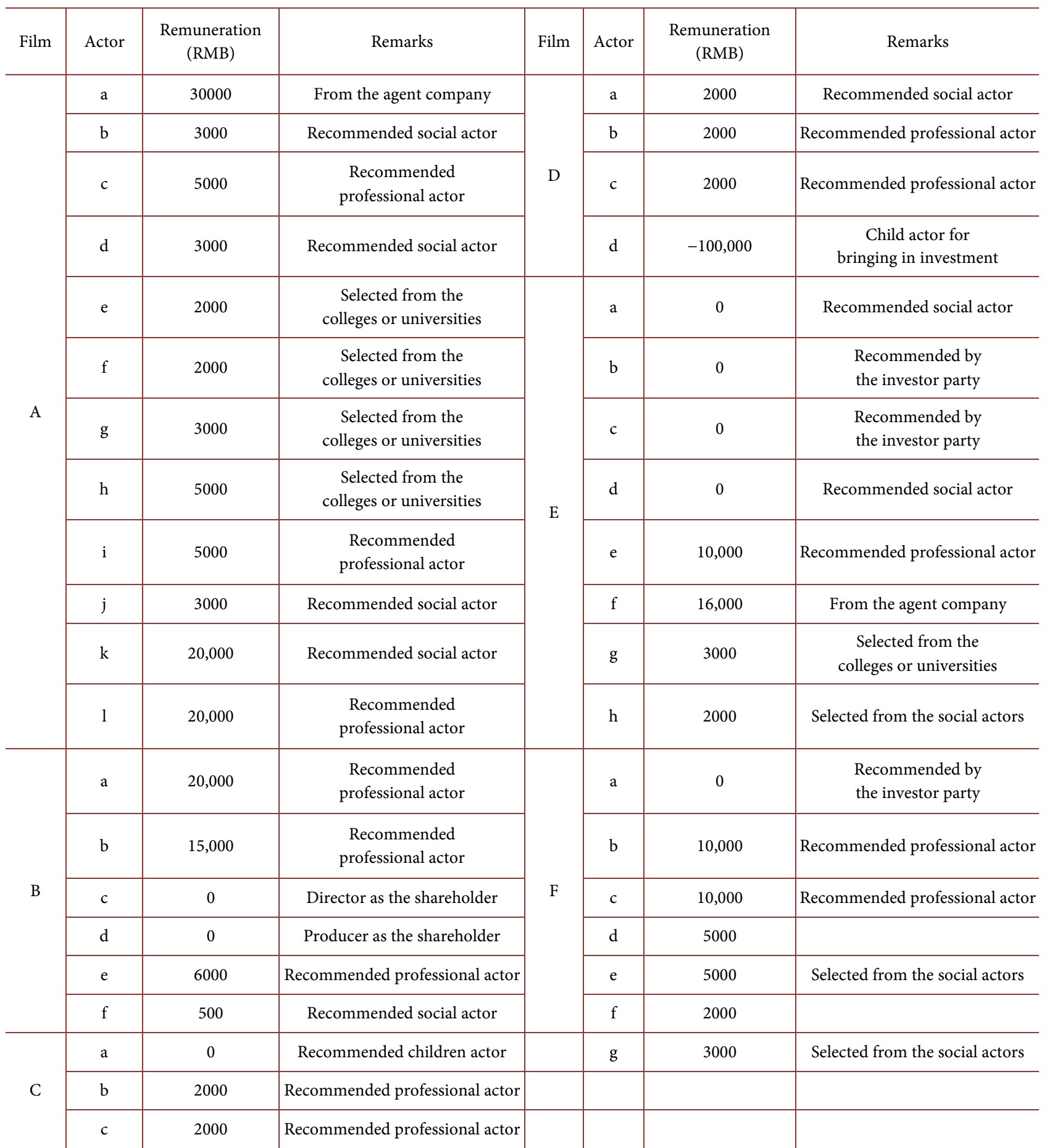

Data Source: from the production units in six small-budget film cases in this study. 
Material costs mainly include expenses of scenes, clothing, makeup, props, and scenery. Small-budget films are mostly modern or contemporary ones, so their cost in this area is small. The scenes are basically ready-made, and there is almost no need to set up scenes specially. Therefore, the film crew should use their own resources and connections to try to use the free scenes; thus, the outreach producers here are quite crucial. The outreach producers are mostly locals. Lots of outreach producers collude with the scene party and raise the price of the original free scenes when making offers for the film crew, accordingly they appropriate the gains to themselves. Sometimes, they reach agreement with the scene party, raise the original price to a higher price and then make that offer to the film crew. Finally, the outreach producer and the scene party divide the money proportionally. Most of the regular clothing is brought into the film crew by the actors themselves. Even if they buy or have others make it, there will be no big difference in cost. However, there will be great flexible space for the cost when there are special requirements for clothing. That's because this type of clothing is often tailored or rented, which involves the local costume market. Actually, the costumers are quite familiar with this field and usually have several long-term fixed cooperation objects. Many costumers customize or rent clothing at the lowest cost, and make an offer for the film crew at a high price. What is more, they often make the offer for the film crew just before the filming with an aim to leave the film crew no time to examine the cost of clothing. The most important thing about make-up is the quality of cosmetics. The cosmetics used in producing films are different from the cosmetics used in life. At present, almost all the cosmetics in Chinese film crews are sold by a shop at the entrance of Beijing Film Studio, and they are all international famous brands. The generally used cosmetics are easy to cause skin allergies. If something happens to the actors, the consequences are unimaginable, which will not only affect the shooting progress, but also result in compensation paid to the actors. Usually, the cost of a small-budget film is about 6000 to 10,000 RMB. Especially, the actress's makeup consumes a lot of cosmetics. Many make-up men accumulate some cosmetics that have not been used by other film crews. When the crew invites the make-up man, the make-up man can also bring his or her own cosmetics into the film crew and the film crew only needs to pay about $50 \%$ of the cost. The cost of cosmetics is great, and if there are many characters, the cost of cosmetics will be higher. The most worrying thing is that the make-up man has the fluke mind to buy low-quality cosmetics at a high price and make profit from it. In the small-budget films, the props and the scenery are usually completed by the arts designer. According to the actual situation, the arts designer chooses to buy the ready-made material or self-made material. Both methods involve the purchase cost. Sometimes, the cost of some props and scenery is quite high, and many arts designers gain extra income from this and the amount is astonishing.

Three departments mainly involve the equipment rental: production unit, lighting unit, recording unit, and vehicles for various departments. The forms of 
rental are divided into several types. The rental forms can be divided into daily rental, weekly rental, and monthly rental, etc., in terms of time and can be divided into single-piece rental and multi-package rental. The small-budget film shooting is mostly packaged and rented according to the planned period. Among the rented equipment, the equipment of the production unit is the most complicated. The camera used in the small-budget films put on in the cinema is "ALEXA" or "ALEXA mini". "5D2" can be used for producing the film only broadcasted on the network. The price of the former model times that of the latter model. The most important thing about the camera is the lens. The ALEXA camera is usually equipped with a UP lens and the price of the substitute CP lens is slightly lower, while the price of the LEICA lens will be higher. Accessories such as tripods, monitors, etc. are equipped with the above lens. In addition, there is a crew member following the equipment. Other accessories are rocker arm, track, Steadicam, aerial photography aircraft, etc. There is usually a lower package price for camera, rocker arm and track, and only one operator is responsible for all packaged accessories. Aerial cameras can be divided into large aerial photography aircraft and small aerial photography aircraft based on the shooting situation. The size and clarity of the scenes shot by them are completely different, and the prices of them are naturally very different. The aerial photography aircraft are usually equipped with two operators. All photographic equipment prices are generally calculated on a daily basis. All items including lighting equipment are packaged and rented together. If the production duration lasts for less than 7 days, the total rental expense is calculated on a daily basis; if the duration lasts for more than 7 days and less than one month, then the rental expenses are certain. It is impossible to complete the production within seven days. Recording equipment is usually accompanied by the crew of the recording unit. The price is also calculated based on the equipment and the crew together, usually a recording engineer and two recording assistants. The vehicles needed in the film crew usually involve power-generating cars, buses, commercial vehicles, small trucks, and the price of vehicles are all calculated with the drivers. The most used brands for commercial vehicles are Ruifeng and Jinbei, and the small trucks are used to install various equipment, clothing and props, etc. This series of equipment and vehicles for small-budget films are almost all rented. In the rental process, it is difficult to have a uniform market price standard. The price of the same equipment rented to different people varies, and there may be a multiple of the difference in price. The experience, status and social connections of the producer in the industry influence the rental expense. If a layman or a newcomer engages in related management work, the cost of investing in this area will increase a lot due to their lack of experience and social connections. By virtue of the observation of the six cases and the comparison of the prices of the main rental equipment, the lowest prices of all main equipment are sorted out (Table 3). If calculated according to the 20-day shooting cycle, the basic equipment rental expenses will be calculated according to the lowest price. Among 
Table 3. The Minimum Price List for Major Rental Equipment.

\begin{tabular}{|c|c|c|c|c|}
\hline Department & Description & \multicolumn{2}{|c|}{ Expense } & Remarks \\
\hline \multirow{9}{*}{ The production unit } & $5 \mathrm{D} 2$ & \multicolumn{2}{|c|}{ 300/day } & $\searrow$ \\
\hline & ALEXA & \multicolumn{2}{|c|}{ 2000/day } & Including the costs of monitors, UP lens, 1 opera- \\
\hline & ALEXAmini & 3000/day & \multirow{4}{*}{$3600 /$ day } & Including the costs of monitors, UP lens, 1 opera- \\
\hline & large rocker arm & $500 /$ day & & \multirow{4}{*}{ Including the cost of 1 operator } \\
\hline & small rocker arm & 150/day & & \\
\hline & track & $300 /$ day & & \\
\hline & Steadicam & \multicolumn{2}{|c|}{ 500/day } & \\
\hline & Large aerial photography aircraft & \multicolumn{2}{|c|}{$8000 /$ day } & Including the cost of 1 operator \\
\hline & Large aerial photography aircraft & \multicolumn{2}{|c|}{ 2000/day } & Including the costs of 1 operator \\
\hline The lighting unit & A whole set of lightings & \multicolumn{2}{|c|}{$25,000 /$ month } & $\searrow$ \\
\hline The recording unit & A whole set of recorders & \multicolumn{2}{|c|}{ 2500/day } & Three persons \\
\hline \multirow{5}{*}{ Vehicles } & Power-generating cars & \multicolumn{2}{|c|}{ 400/day } & Including the costs of 1 driver and operator \\
\hline & Buses & \multicolumn{2}{|c|}{$800 /$ day } & Including the cost of 1 driver \\
\hline & Commercial vehicle (Ruifeng) & \multicolumn{2}{|c|}{ 280/day } & including the cost of 1 driver \\
\hline & Commercial vehicle (Jinbei) & \multicolumn{2}{|c|}{ 240/day } & Including the cost of 1 driver \\
\hline & Small truck & \multicolumn{2}{|c|}{ 350/day } & Including the cost of 1 driver \\
\hline
\end{tabular}

Data Source: from the production units in six small-budget film cases in this study.

them, the expenses of renting Ruifeng, Jinbei and mini-trucks are calculated based on two vehicles, and the basic necessary equipment in the photographic equipment only includes packaged equipment with the total price being 205,800 RMB. The application of Steadicam or aerial photography aircraft will increase the total expense. If a layman or a newcomer is in charge of the production management, the expenses of this series of equipment cannot be estimated, and may be over 400,000 RMB. In addition, the management party should also rationalize the rental management of these equipment and vehicles according to the needs of the shooting and the production cycle so as to minimize the unnecessary expenditure.

The food and accommodations expenses account for a large proportion of the total cost of the film crew. Local consumption levels of different shooting venues also have different degrees of disparity. The film crew should try to use their own resources to seek sponsorship, and try to reduce or exempt the food and living expenses as much as possible. For example, the film crew can provide the hotel with naming right or use the hotel as production venue to make product placement for advertising the hotel. In addition, the life producers should try to seek food and accommodations themselves instead of depending on the intermediary to avoid the risk of increased expenses. The most noteworthy part of the living expenses is the vehicle oil expense. The situation of drivers stealing oil exists in every film crew more or less, which has become the unspoken rule of the industry. Many experienced managers have already known about this but have no direct evidence to blame the drivers. Therefore, as long as the drivers restrain 
themselves, most of the production directors generally do not easily disclose them. The driver's salary in the film crew is usually 80 to 100 RMB per day; and that of the bus driver is generally $150 \mathrm{RMB}$, and the power-generating cars driver's salary ranges generally from 150 to $200 \mathrm{RMB}$. Their income is not high, so many of them rely on other means to supplement their income. If calculated according to a 20-day production period, the oil expense can amount up to 4000 $\mathrm{RMB}$, thus increasing the pressure on the funds of the film crew. However, the oil expense of a car can be controlled within $1000 \mathrm{RMB}$, with an average of 50 RMB per day. In this case, the production director will not interfere too much. There are still many unpredictable costs in life, such as the cost of public relations and film crew dinners, the cost of purchasing insurance, the medical expenses for sickness and injury, etc. These are unpredictable costs but exist objectively to a certain degree.

In general, the main costs of small-budget films in film production are roughly divided into three categories according to the control attributes (Figure 1). Among them, actors and scene producers only consider whether this price is acceptable or not and it is difficult for them to control the real value of the selected party. The real value refers to the price actually obtained by the selected party or the actual market value. The producer can control the costs invested in personnel, costumes, make-up, props and scenes, equipment rental, vehicle rental, food and accommodation, vehicle refueling, public relations and dinners within a certain range and estimate their prices within certain limits; for example, the costs of insurance and medical care are more specific, which can be fully controlled by the producer and every expenditure can be clearly grasped.

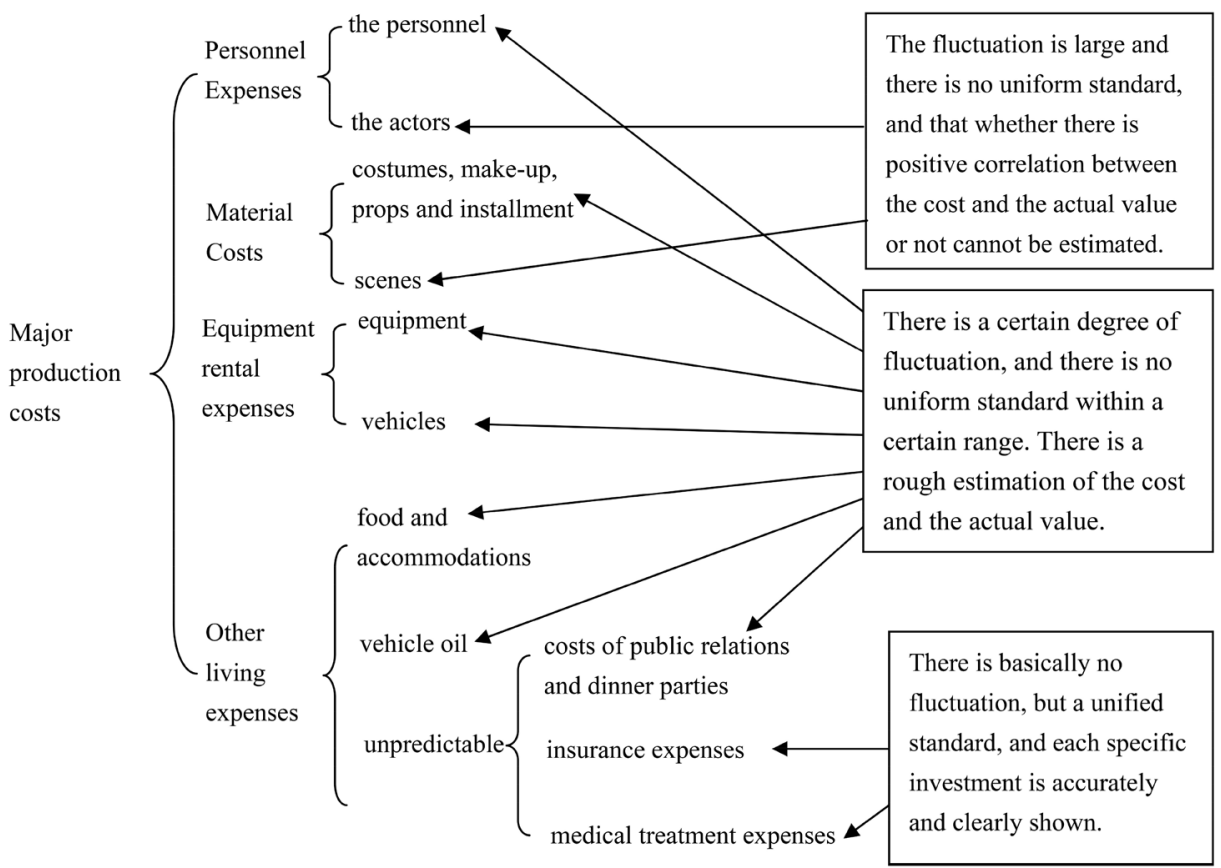

Figure 1. The attributes of cost control in small-budget film production. Data source: The above figure is drawn from the discovery of the author. 


\section{Conclusion}

The investors and producers of small-budget films are mostly laymen, which is an important reason for the increase in cost during the production process. The costs of personnel account for the largest proportion of investment. Among them, in terms of the costs of personnel, there are certain fluctuations due to human favors. As for the total costs of the entire staff, the cost fluctuation of personnel at lower strata is less influenced by human favors. However, the overall cost of personnel is relatively fixed, while the cost disparity of the main actors is huger. Sometimes, the price is not proportional to the quality. Thus, a principle should be grasped in choosing the main actors: "right actors should be chosen rather than expensive ones. The cost of the non-main actors is relatively fixed. In addition, the casting director's taking "kickback" phenomenon which leads to an increase in the cost of the film crew should be prevented in choosing actors. Most of the costs invested in materials can be estimated, because the damage caused by human factors is very small, and the producers should actively communicate with the parties or departments. Only the cost of the scenes is more abstract and unpredictable. Also, the crossing-border behavior of outreach producers in the scenes should also be prevented to avoid an increase in the cost of the film crew. The equipment rental requires the producer to have a certain personal relationship so as to rent the required equipment at a low price. In addition, a reasonable plan for the rented equipment in the use period should be formulated to avoid unnecessary waste. It needs to be taken into consideration that whether the living costs can be changed with the film crew's own resources firstly. The living costs should be appropriate and reasonable and should not be too economical, but the crossing-border behavior of drivers should be paid more attention to. Generally speaking, there is no need to worry too much about fully controlling the cost. To control the cost to a certain degree, the producers should communicate with the parties more and more to arouse attention of the latter, and the producers must establish certain prestige in the other parties' mind. The uncontrolled and abstract costs are judged and determined according to the experience and the keen social insight of the producer.

\section{The Limitations of the Study}

The case data collected in this study are reminiscent narrative. Although the data deriving from the personal experience of the author are true and reliable, there is no further analysis on the cause and effect of the incidents.

The veterans interviewed in this study are involved in some sensitive topics and inevitably have some reservations. In particular, there may be no objective judgments on the specific related work issues that the parties are engaged in. Some negative problems may involve the parties themselves, and the other parties may avoid making any reply, or just make a reply with non-authentic phenomena.

Since the object of this study "China's small-budget film" is a newly emerging thing in recent years, there are very few documents on the research of related issues. Therefore, the data applied in this study are mostly two types of data: prac- 
tice observation and in-depth interview and literature data is rarely applied.

The research questions are supported by multiple data as much as possible in order to greatly increase the reliability and validity of the study and subjective insights of the researcher in the research process still exist inevitably.

\section{Conflicts of Interest}

The author declares no conflicts of interest regarding the publication of this paper.

\section{References}

[1] Cao, L.Q. (2011) Research on Application of Project Management in Video Recording of Movie \& Television. Master's Thesis, Tianjin University, Tianjin.

[2] Zhao, H.C. and Zhao, J.C. (2010) An Interview with Zhao Haicheng. Contemporary Cinema, 27, 67-70.

[3] Sun, B. (2016) A Comparative Study on Management Mechanism of Film Production between China and the United States. Art Science and Technology, 29, 35.

[4] Sohu Finance (2018) Comprehensive Analysis on the Profit and Loss of 2017 Chinese Film TOP 100. https://www.sohu.com/a/221548578_473379

[5] Fang, L. (2007) Program and Management in Process of Film Making. Master's Thesis, Sichuan University, Chengdu.

[6] Bu, S.S. (2012) Discussion on Cost Control in Film Production. Chinese Film Market, 62, 12-13.

[7] Zheng, D.T. (2009) The Market Outlet of the Film with Low Budget. Contemporary Cinema, 26, 14-24

[8] Doloi, H.K. (2011) Understanding Stakeholders' Perspective of Cost Estimation in Project Management. International Journal of Project Management, 29, 622-636. https://doi.org/10.1016/j.ijproman.2010.06.001

[9] Jackson, G. (2012) Contingency for Cost Control in Project Management: A Case Study. The Australian Journal of Construction Economics and Building, 3, 1-11. https://doi.org/10.5130/AJCEB.v3i1.2906

[10] Si, J. (2014) Discussion on the Problems That Should Be Paid Attention to in the Cost Accounting of Film and Television Industry. China Chief Financial Officer, 12, 118-119.

[11] Chen, G.Z. (2018) Study on the Cost Control in Film and Television Industry. China Civil Entrepreneur, 6, 143-144.

[12] Wang, X.H. (2017) The Applied Research of the Cost Control in Film and TV Programs. Accountant, 14, 37-38.

[13] Li, F.J. (2018) The Application of Project Management in Cost Control of Film and TV Plays. China Chief Financial Officer, 16, 58-59.

[14] Long, L.F. (2015) The Cost Control of Film Production. Chinese Film Market, 65, 28-30.

[15] Li, Y.C. (2016) Several Problems of the Cost Accounting in Film and Television Industry. Business, 6, 172.

[16] Eisenhardt, K.M. and Graebner, M.E. (2007) Theory Building from Cases: Opportunities and Challenges. Academy of Management Journal, 50, 25-32. https://doi.org/10.5465/amj.2007.24160888

[17] Crabtree, B.F. and Miller, W.L. (1999) Doing Qualitative Research. Sage Publications, California. 